\title{
Foliage Spraying Molybdenum Promotes Plant Growth and Controls Soilborne Ralstonia solanacearum in Different Tobacco Varieties
}

\author{
Chen $\mathrm{J}^{1 *}$, Zheng $\mathrm{S}^{1 *}$, Du $\mathrm{G}^{1}$, Wang $\mathrm{D}^{2}$ and Ding $\mathrm{W}^{1 *}$ \\ 'Laboratory of Natural Product Pesticide, College of Plant \\ Protection, Southwest University, Chongqing, PR China \\ ${ }^{2}$ Tobacco Scientific Research Institute of Chongqing, \\ Chongqing, PR China \\ \#Contributed Equally to this Work \\ *Corresponding author: Wei Ding, Laboratory of \\ Natural Product Pesticide, College of Plant Protection, \\ Southwest University, Chongqing, 400715, PR China
}

Received: February 23, 2021; Accepted: March 19, 2021; Published: March 26, 2021

\begin{abstract}
Tobacco growing is greatly threatened by the devastating bacterial wilt disease caused by soil-borne bacteria Ralstonia solanacearum $(R$. solanacearum). Balanced plant nutrition has become effective strategy for crop disease management. In this study, we firstly conducted greenhouse and field experiments to investigate the effects of Molybdenum (Mo), acting as a foliar fertilizer, on tobacco plant growth and bacterial wilt control. A susceptible variety (Yunyan 87) and a moderately resistant cultivar (Nanjiang 3) were used in this study. Under greenhouse condition, the results demonstrated that the disease incidence in the Mo-treated plants decreased to $41.7 \%$ (Yunyan 87) and $44.4 \%$ (Nanjiang 3 ) compared with that of non-Mo-treated plants. The control mechanisms are related to the reduced bacteria colonializations in tobacco and improvement of defense enzymes including peroxidase, catalase, superoxide dismutase, polyphenol oxidase and phenylalanine ammonialyase. Malondialdehyde levels halved after $200 \mathrm{mg} / \mathrm{L}$ Mo treatment compared to the control group. The field experiment results also showed that supplements of $200 \mathrm{mg} / \mathrm{L}$ Mo significantly decreased the disease incidence by $30.3 \%$ and $33.9 \%$, respectively. Moreover, foliar application of Mo increased plant growth under both growth conditions, promoting leaf and root development. Mo was taken up by tobacco leaves, but the content decreased during the growth of plants. Mo application could provide an alternative strategy for efficient management of tobacco bacterial wilt, even in crops other than tobacco, especially in Modeficient planting regions, which would have a great impact on agriculture and favor sustainable agriculture development.
\end{abstract}

Keywords: Molybdenum; Tobacco; Bacterial wilt; Control efficacy; Defense enzymes

\section{Introduction}

Bacterial wilt, caused by $R$. solanacearum, is one of the most devastating soil-borne bacterial diseases in Chongqing tobacco growing areas. The disease predominantly occurs in tropical, subtropical and temperate soils [1,2], but it can spread to areas at high latitudes and high elevations. Due to the complex diversity of host plants, pathogenicity, and infectious conditions, it is difficult to develop highly effective measures to protect plants from infection [3]. Integrated management strategies that include biological and chemical compounds, and resistant varieties are applying to resisting the disease $[4,5]$. However, excessive use of bactericides has caused adverse impacts on ecological environments and human health [6], consequently hindering sustainable agricultural crop production, especially for the Solanaceae family of plants. Therefore, it is essential to explore more sustainable and effective approaches to manage bacterial wilt, protecting yield and improve product quality.

Recent studies have proved that it is important to manage nutrient balance through foliar fertilizers or soil amendments to influence nutrient availability and in that way to control bacterial wilt disease [7]. Organic fertilizer applications, soil amendments, and soil $\mathrm{pH}$ adjustments have attempted to provide nutrition strategies for this problem to some extent, such as $\mathrm{K}, \mathrm{Mg}$ and $\mathrm{Mn}$, reducing the susceptibility of plants to disease [5]. At present, tobacco is commonly grown in more than 10 provinces in China and bacterial wilt is the most prevalent and economically important disease especially in Chongqing, which is associated with soil acidification, ultimately, reduces mineral nutrients available for plants [8]. Some nutrients have been successfully implicated in bacterial and fungal disease management strategies, i.e. Silicon (Si), Calcium (Ca), Potassium (K), Phosphorus $(\mathrm{P})$ and Nitrogen $(\mathrm{N})$ reduced the incidence and severity of bacterial wilt and increased plant resistance [7-12]. An increase in Boron (B) dramatically reduced the tomato bacterial wilt and lead to a better performance in resistant varieties [8]. It was proposed that a combination of increased $\mathrm{H}_{2} \mathrm{O}_{2}$ content and Peroxidase (POD) and Polyphenol Oxidase (PPO) activities in the tomato plants played a role in the improved performances of the resistant varieties. Foliar applications and soil amendments with Mo fertilizers have also reduced various bacterial and fungal diseases in plants, such as tomato Verticillium wilt [13], common bean angular leaf spot (Phaeoisariopsis griseola) [14] and common bean anthracnose (Colletotrichum lindemuthianum) [15]. However, the effect of Mo in the management of bacterial wilt diseases is still not known.

Mo plays an essential role as a catalytic metal for various enzymes
Ann Agric Crop Sci - Volume 6 Issue 2 - 2021

ISSN: 2573-3583 | www.austinpublishinggroup.com

Ding et al. $@$ All rights are reserved
Citation: Chen J, Zheng S, Du G, Wang D and Ding W. Foliage Spraying Molybdenum Promotes Plant Growth and Controls Soilborne Ralstonia solanacearum in Different Tobacco Varieties. Ann Agric Crop Sci. 2021; 6(2): 1074. 
in plants, including nitrate reductase, aldehyde oxidase, xanthine dehydrogenase/oxidase, and aldehyde oxidase [16]. Desirable soil levels for plants range from 0.5 to $5 \mathrm{mg} / \mathrm{kg}$ soil [17]. Mo deficiency induces reduced Molybdenum cofactor (Moco) biosynthesis and Mo enzymes activities, decreasing in quality and yield and intensifying disease symptoms by a lack of micronutrients $[16,18]$. Characteristics of Mo deficiency in tobacco include leaf mottling or interveinal necrotic areas that gradually developed until the entire leaf wilts. Yield loss is common, eventually increasing the plant susceptibility to bacterial wilt, especially in acidic planting fields $[19,20]$. In addition, previous studies have shown that Mo has beneficial effects against disease development and on plant physiology. The area under the disease progress curve of Anthracnose decreased by $38 \%$ after a foliar application of NaMo (20 $\mathrm{g} \mathrm{Mo} \mathrm{ha}^{-1}$ ) to beans 25 days after sowing [14]. Foliar application of Mo reduced the Verticillium wilt of tomato (Lycopersicon esculentum Mill.) by $18 \%$ to $37 \%$ [12]. Limited Mo phytotoxicity was observed in tomato and cauliflower in the field condition [21]. In addition, Mo has shown excellent antimicrobial activity against phytopathogenic fungi (Phytophthora cinnamomi, Phytophthora drechsleri and Rotylenchus reniformis) during in vitro studies [22].

Moreover, Mo supplementation improved the frost, cold and salt stress tolerance of winter wheat, which was attributed to the enhancement of the antioxidant enzymes activities of Peroxidase (POD), Catalase (CAT), and Superoxide Dismutase (SOD) and an osmotic adjustment that resulted in greater $\mathrm{K}^{+} / \mathrm{Na}^{+}$ratios [23-26]. In addition, many studies have shown that pathogens infections in host plants can result in an increased production of active oxygen species such as superoxides, hydroxyl radicals, and superoxide radicals [27]. Malondialdehyde (MDA) can be used to indicate the level of oxidative stress, which can damage cell membranes and disintegrate biological cells [28]. However, the relationship between Mo and tobacco bacterial wilt has not yet been elucidated.

Therefore, in this study, based on theoretical and practical foundation, we investigated whether Mo effectively control bacterial wilt under field and greenhouse condition by foliar application. Furtherly, toxicity of Mo on R. solanacearum in vitro and the effect of Mo on the growth of two tobacco varieties (susceptible and moderately resistant) were evaluated. The uptake of Mo and changes in defense enzyme activities between Mo-deficient and Mo-supplied plants were studied to elucidate the regulatory mechanism of tobacco resistance against bacterial wilt. The study holds great promise regarding their application in plant protection and nutrition for development as a new potentially disease management strategy.

\section{Materials and Methods}

\section{Greenhouse experiment}

Plant materials and growth conditions: The tobacco (Nicotiana tabacum) cultivars Yunyan 87 and Nanjiang 3, which are susceptible and moderately resistant to bacterial wilt, respectively, were used for greenhouse experiments. Yunyan 87 was produced by the Yunnan tobacco scientific research institute through hybridization breeding. It is a popular variety in most areas of China because of its wide adaptability and high yield. Tobacco seeds were sown in a floating seedling system filled with commercial matrix (Hunan Xianghui Agriculture Technique Development Co. Ltd), containing a very low level of Mo content $(0.007 \mathrm{mg} / \mathrm{kg})$. Seedlings were watered regularly and fertilized twice weekly with $\mathrm{pH}$ 6.0 Mo-free Hoagland solution (diluted to 1:40 medium: sterile water). All plants were placed in a growth chamber (MA-835/2106UR; Marconi) until the four-leaf stage (approximately two months) at $30^{\circ} \mathrm{C} / 27^{\circ} \mathrm{C}$ (day/night), with a relative humidity of $85 \sim 90 \%$, photoperiod of $14 \mathrm{~h}$ and light intensity of $320 \mu \mathrm{mol} \cdot \mathrm{m}^{-2} \cdot \mathrm{s}^{-1}$ (Philips TL-D 36W/840). Then, the seedlings were transplanted into polyethylene pots $(80 \mathrm{~mm}$ diameter $\times 80 \mathrm{~mm}$ height $)$ filled with $200 \mathrm{~g}$ of humus medium.

Inoculum preparation: $R$. solanacearum strain (CQPS-1, Biovar 3 , Phylotype I), was isolated from infected tobacco in the Chongqing and purified by the Laboratory of Natural Product Pesticide, Southwest University (SWU). The strain used in this study is highly virulent to tobacco [29]. For inoculation, CQPS-1 was cultured on Nutrient Broth (NB) medium (3g beef extract, $10 \mathrm{~g}$ peptone, $5 \mathrm{~g} \mathrm{NaCl}$, and $1000 \mathrm{~mL}$ deionized water, $\mathrm{pH} 7.0$ ) and grown for one night at $28^{\circ} \mathrm{C}$. The resultant $\mathrm{NB}$ culture was centrifuged, the supernatant was disposed and the bacterial cell pellet was suspended in deionized double distilled water that had been purified with a Milli-Q system (Millipore Corp., Bedford, MA, USA). The inoculum suspension was adjusted to $10^{7} \mathrm{CFU} / \mathrm{mL}$ using a WGZ-2-XJ bacteria turbidimeter (Xinrui Co. Ltd, China) and used immediately.

Growth chamber assays to assess the effect of Mo and $\mathrm{N}$ on bacterial wilt: As abovementioned, two tobacco cultivars (Yunyan 87 and Nanjiang 3) were grown until the development of the fourth leaf. Four concentrations of Mo solutions were prepared using $\left(\mathrm{NH}_{4}\right)_{6} \mathrm{MoO}_{24} \cdot 4 \mathrm{H}_{2} \mathrm{O}$ (Sigma-Aldrich, USA), resulting in elemental Mo contents of $0.2 \%, 0.10 \%, 0.05 \%$, and $0.02 \%$ (w/v), namly, $200 \mathrm{mg} / \mathrm{L}$, $100 \mathrm{mg} / \mathrm{L}, 50 \mathrm{mg} / \mathrm{L}$ and $200 \mathrm{mg} / \mathrm{L}$. To eliminate the role of the nitrogen source, treatments with different concentrations of ammonium nitrate $\left(\mathrm{NH}_{4} \mathrm{NO}_{3}\right)$ (Sigma-Aldrich, USA) treatments $(0.0037 \%$, $0.0075 \%, 0.015 \%, 0.03 \%$ ), namly, $3.7 \mathrm{mg} / \mathrm{L}, 7.5 \mathrm{mg} / \mathrm{L}, 15 \mathrm{mg} / \mathrm{L}$, and $30 \mathrm{mg} / \mathrm{L}$, which were corresponding equivalent to the corresponding molar nitrogen values of the different ammonium molybdate treatments, were used. For the control group, the tobacco seedlings were watered with distilled water. For the treatments, the nutrient solutions were sprayed onto the tobacco plants using an atomizer. For each plant, both leaf surfaces of each plant were sprayed until run-off, which amounted to $20 \mathrm{~mL}$ solution per seedling. Seven days after treatment, tobacco plants were inoculated with $R$. solanacearum using the root-drenching method. Briefly, we inserted a long, narrow blade into the pot at four positions to damage the roots. Then, $20 \mathrm{~mL}$ of the $R$. solanacearum inoculum suspension was poured around the base of each plant. For the non-inoculated control plants, $20 \mathrm{~mL}$ of distilled deionized water was poured around the base of each plant. Following the inoculation, the plants were returned to the growth chamber described above. Pots were arranged in a randomized block design that consisted of 36 replications per treatment. Each plant was considered a replication. Three plants per treatment were randomly selected and sampled at $6 \mathrm{DAI}$ for enzyme quantification, while 33 plants were maintained for symptom evaluation. The experiments were conducted three times.

To determine the effect of Mo on tobacco plants growth, the same four Mo solutions or distilled water (negative control) were applied to tobacco plants at the four-leaf stage as described above. Pots were arranged in a randomized block design that consisted of 30 replications 
(plants) per treatment. The following growth characteristics were recorded for each plant 20 days after treatment: plant fresh weight, plant dry weight, root fresh weight and stem length.

Measurement of $R$. solanacearum populations in tobacco roots and stems: Under greenhouse condition, the roots and stems $(1 \mathrm{~cm}$ above roots) of the tobacco plants were sampled at 1, 7, 14 and 21 days (DAI), washed with sterilized DI water and then, dried on filter paper. For the tested plants, $0.5 \mathrm{~g}$ of roots or stems were immersed in $75 \%$ ethanol for 20 s, and rinsed with sterilized DI water three times. The roots or stems were ground in a mortar containing $1 \mathrm{~mL}$ of sterile water. A serial dilution from $10^{-1}$ to $10^{-8}$ times of the homogenate was prepared in sterile distilled water. A total of $100 \mu \mathrm{L}$ from each dilution were spread onto NA agar plates containing $0.1 \%$ TTC. The plates were placed in an incubator at $30^{\circ} \mathrm{C}$ for three days, and the number of representative colonies was counted. All treatments were individually repeated at least three times.

Effects of foliar-applied Mo on defense enzyme activity and MDA level: For all Mo, N and control groups, leaf samples (a mixture of one oldest leaf and one youngest leaf of one tobacco plants) of Yunyan 87 were collected 6 DAI in the greenhouse, which corresponded to the early onset of the disease. Three seedlings per treatment were collected. A sample of the leaf tissue $(0.5 \mathrm{~g})$ was homogenized in $5 \mathrm{~mL}$ of borate extraction buffer, which was consisted of $0.2 \mathrm{M}$ borate buffer ( $\mathrm{pH} 8.8$ ), $5 \mathrm{mM} \beta$-mercaptoethanol (Sigma-Aldrich, USA), 1mM EDTA (Sigma-Aldrich, USA) and a small quantity of PVP (Sigma-Aldrich, USA), in an ice bath. The supernatants were collected by centrifugation at $12000 \mathrm{rpm}$ for $20 \mathrm{~min}$ at $4^{\circ} \mathrm{C}$ and sampled to measure the activity of enzymes. Changes in the enzyme activity of the healthy tobacco plants after the foliar Mo application but without the $R$. solanacearum inoculation were also measured in parallel.

The POD activity was assayed in accordance with previous method [8]. The CAT activity was determined in accordance with the method described [30]. A change in absorbance of 0.1 was defined as one Unit (U). The SOD activity in the extract was measured using a SOD kit (Beyotime, China). The absorbance at $560 \mathrm{~nm}$ was measured using a UV1000 spectrophotometer. The enzyme quantity resulting in $50 \%$ inhibition of NBT photoreduction was defined one Unit $(\mathrm{U})$. The PPO activity was quantified using a $3 \mathrm{~mL}$ reaction mixture consisting of $2.95 \mathrm{~mL}$ of $0.02 \mathrm{M}$ catechol ( $\mathrm{pH} 6.8$ ) and $50 \mu \mathrm{l}$ of crude enzyme extract [8]. A change in absorbance of 0.1 was defined as one Unit (U). The PAL activity was measured and calculated using previously described methods [31].

MDA was measured in a $4 \mathrm{~mL}$ reaction mixture containing $2 \mathrm{~mL}$ of $0.6 \%(\mathrm{w} / \mathrm{v})$ Thiobarbituric Acid (TBA) solution and $2 \mathrm{~mL}$ of crude enzyme extract. After the mixture was quickly cooled and centrifuged (12000g, 20min), the absorbance of the supernatant was measured at 532, 450 and $600 \mathrm{~nm}$. The content of MDA in the extract was calculated as described previously [28].

\section{Field experiments}

Soil sampling and properties measure: Field experiments were also conducted at the Qianjiang tobacco planting area in Chongqing. Tobacco has been cultivated for more than ten years at this site, which is geographically located at $29^{\circ} 19^{\prime} \mathrm{N}$ and $108^{\circ} 36^{\prime} \mathrm{E}$ at an altitude of
$750 \mathrm{~m}$. Bacterial wilt was prevalent at the site. In July, August, and September of both years, the weather was rainy, and the average monthly temperature ranged from 24 to $27^{\circ} \mathrm{C}$, which is considered suitable for bacterial wilt development.

Soil cores were sampled at an approximate depth of 5 to $20 \mathrm{~cm}$ using a soil probe $(5 \mathrm{~cm}$ diameter $\times 15 \mathrm{~cm}$ depth). Five soil samples were collected from each sampling area (diameter $100 \mathrm{~m}$ ) and mixed to form a composite sample. After the removal of plant residues and stones, the soil was ground and sifted using a 60-mesh nylon membrane sieve, after which the samples were stored at $4^{\circ} \mathrm{C}$ until further use.

The soil physicochemical properties and nutrient indicators, including $\mathrm{pH}$, organic matter, available nitrogen, phosphorus, potassium, and Mo content were determined for each soil sample. Alkaline hydrolysis diffusion was used to determine nitrogen [32]. The dichromatic oxidation titration method was used to analyze organic matter content [33]. The Flame Atomic Absorption Spectrometry (FAAS) method was used to determine the available K, Fe and Mo [34]. The planting date, harvest date, the onset date of disease and the ending date of disease are presented in Table S1.

Field experimental design and disease severity assessment: Yunyan 87 and Nanjiang 3 tobacco seedlings with six or seven leaves were transplanted into the selected plots at Qianjiang. We planted both varieties from May to September. The two whole test plots covered approximately an area of $1000.5 \mathrm{~m}^{2}$. Each variety was planted as a separated block with a randomized selection. Each experimental plot was zoned into five rows of $5 \mathrm{~m}$ in length with $1.5 \mathrm{~m}$ row spacing. Tobacco plants spacing in the rows was $0.5 \mathrm{~m}$ (15000 plants ha $\left.^{-1}\right)$; thus, there were 80 plants per plot. The treatments consisted of four levels of Mo supplementation using the same concentrations as those in the greenhouse experiment. Briefly, Mo was applied as a foliar spray to tobacco at three growth stages: the seedling stage (14 days after transplanting, (DAT)), the rosette stage (45 DAT), and the strong rapid growth stage (55 DAT). A complete randomized block design with three replications was used. Commercial fertilizers were applied to the entire experimental area prior to transplanting. Specifically, there were $50 \mathrm{~kg}$ of special tobacco compound fertilizer (9-12-25) per $667 \mathrm{~m}^{2}, 30 \mathrm{~kg}$ of organic fertilizer (organic matter $\geq 30 \%, \mathrm{~N}-\mathrm{P}_{2} \mathrm{O}_{5}$ $\left.\mathrm{K}_{2} \mathrm{O} \geq 4.0 \%\right)$ per $667 \mathrm{~m}^{2}, 15 \mathrm{~kg}$ of potassium nitrate (13.5-0-44.5) per $667 \mathrm{~m}^{2}$ and $2.5 \mathrm{~kg}$ of ammonium nitrate-phosphorus (30-6-0) per $667 \mathrm{~m}^{2}$. During the period from 60 to $75 \mathrm{DAT}$, when approximately $50 \%$ of the plants in each plot were in at full bloom, the terminal inflorescence of each plant was removed when the plant had 16 to 20 leaves. A suckercide (12.5\% flumetralin EC) was applied to all tobacco plants to prevent lateral shoots from developing. Bacterial wilt disease indexes were recorded at the initial, infectious, and later stages of disease (45, 75 and 90 DAT, respectively). In addition, the plant height, stem diameter, maximum leaf length, width, and the number of leaves remaining per plant at $75 \mathrm{DAT}$ in the field tests were investigated.

The bacterial wilt disease assessments began with the appearance of leaf symptoms and continued at daily intervals until the plant had died or the symptoms no longer progressed and classified using the standard described in the study of Godiard et al. (in the supporting information) [35]. 
Determination of the Mo content: The concentrations of Mo in tobacco plants were measured at $14 \mathrm{DAI}$ in the greenhouse experiment for the Yunyan 87 cultivar and the Nanjiang 3 cultivar, and at 75 DAT in the field experiment in both years. Briefly, $1 \mathrm{~g}$ of leaf tissue (dry weight) was treated for $2 \mathrm{~h}$ in a microwave digester (SpeedWave ${ }^{\mathrm{TM}}$, MWS-3+, Berghof) with $3 \mathrm{~mL}$ of $65 \% \mathrm{HNO}_{3}$ and $2 \mathrm{~mL}$ of $30 \% \mathrm{H}_{2} \mathrm{O}_{2}$. The digested samples were then diluted with distilled water to a total volume of $25 \mathrm{~mL}$. Rhizosphere soils $(0-15 \mathrm{~cm}$ depth) were sampled for all the treatments in the greenhouse experiments and field tests. After removing the loosely adhering soil by vigorous shaking, soils were sieved (2mm-mesh) to eliminate plant residues and air-dried and prepared as described previously [36]. Then, all the samples were analyzed using the above mentioned FAAS methods on a Perkin-Elmer 5000 instruments. The Mo levels in the stems and roots were also determined using the same procedure.

\section{Antibacterial tests of Mo in vitro}

The antibacterial activity of Mo against $R$. solanacearum was investigated in vitro. A culture of $R$. solanacearum was collected during the exponential growth phase. A $20 \mu \mathrm{L}$ drop of bacterial suspension was pipetted and spread onto sterile solid NB media containing Mo content of 20, 50, 100 and $200 \mathrm{mg} / \mathrm{L}$. The control agar plates contained NB media with no Mo. The plates were incubated for three days at $30^{\circ} \mathrm{C}$. The viable cell number was recorded as the number of bacterial colonies growing on the plate. There were at least three plates for each Mo concentration.

\section{Statistical analysis}

All experiments were performed three times, and the data were expressed as the means of the triplicates. One-way Analysis of Variance (ANOVA) was performed. The treated means were compared using Fisher's protected least significant difference test $(\mathrm{P} \leq 0.05)$ for multiple mean comparisons. The statistical analysis was implemented using the Statistical Product and Service Solutions software (SPSS) (SPSS 16.0, SPSS Inc. USA) for data analysis.

\section{Results}

\section{Physicochemical properties and Mo content of the rhizospheric soil}

As shown in Table S2, the soil samples from Qianjiang were classified as typical yellow soil and contained low organic matter $(18.7 \mathrm{mg} / \mathrm{kg})$, high available nitrogen $(98.4 \mathrm{mg} / \mathrm{kg})$, high available phosphorus $(45.6 \mathrm{mg} / \mathrm{kg})$, and high available potassium $(103.9 \mathrm{mg} / \mathrm{kg})$ contents. Noticeably, the content of Mo in the soil was $0.068 \mathrm{mg} / \mathrm{kg}$. The soil was acidic $(\mathrm{pH}=5.5)$, which was determined in a 1:2.5 $(\mathrm{w} / \mathrm{v})$ soil to calcium chloride suspension. The average active Mo contents of the rhizosphere soil around the infected tobacco plants within the typical tobacco-growing areas in Chongqing were also determined. All were similar, with the exception of the Mo contents in Pengshui, which were also relatively low (Table S3).

\section{Mo accumulation in the soil and tobacco plants}

The Mo accumulation in the soil and leaves of tobacco cultivar Yunyan 87 and in the soil and leaves of tobacco cultivar Nanjiang 3 followed the same trends in both greenhouse and field experiments (Table 1). Compared with control, the leaf Mo content in tobacco gradually increased with increasing applied Mo concentration (20,50, 100 and $200 \mathrm{mg} / \mathrm{L}$ ) under both field and greenhouse conditions. For
Yunyan 87 cultivar, the leaf Mo concentration of the 200mg/L Motreated group was $89.7 \%$ and $62.9 \%$ greater than that of the control in the field test and in the greenhouse test, and $96.8 \%$ and $97.6 \%$ greater for Nanjiang 3. The average Mo content of the rhizosphere soil in the control and Mo-treated was similar. The application of different concentration of $\mathrm{N}$ did not affect Mo uptake efficiency from either the soil and in leaves.

\section{Effects of foliar Mo application on tobacco bacterial wilt under greenhouse conditions}

The potential suppressive effects of Mo were assessed in pot experiments using two tobacco cultivars. Tobacco plant responses to pathogens were evaluated by recording the wilting leaves as descripted in Method and Materials. It can be found the incidence of bacterial wilt varied among treatments in the greenhouse experiment. Symptoms developed after 7 DAI. Though the two tobacco varieties were grown in different years, both the tobacco seedlings treated with $200 \mathrm{mg} / \mathrm{L}$ Mo had a significantly lower $(\mathrm{p}<0.05)$ disease incidence and severity than the untreated controls and began to wilt at $9 \mathrm{DAI}$, whereas the plants under other treatments and in the control group began to wilt at 7 DAI. At $21 \mathrm{DAI}$, the plants in the control groups were wilted, while the incidence of bacterial wilt was $29.2 \%$ for Yunyan 87 and 55.6\% for Nanjiang 3 plants treated with 200mg/L Mo (Figure 1A and 1B). The control efficacies were 40.9\%, 47.3\%, $49.5 \%$, and $56.9 \%$ for Yunyan 87 and $29.2 \%, 38.6 \%, 59.9 \%$, and $63.9 \%$ for Nanjiang 3 respectively (Figure S2). Foliar application of N had no effect on the disease development; the overall disease incidences were similar to those of the control groups (Figure 1C and 1D). It was observed that the untreated leaves became wilted at $15 \mathrm{DAI}$, while the Mo-treated leaves still looked healthy (Figure 1E).

\section{Effects of Mo on defense enzymes activities in tobacco leaves}

To understand Mo-induced tobacco disease resistance to $R$. solanacearum, we observed significant variations among the different resistance-related enzymes in response to the different treatments in infected susceptible tobacco plants (Figure 2A). Compared to the POD activity in the non-amended soil, demonstrably improved with an increase in the Mo concentration. The POD activity increased by $1.3,1.9,2.2$ and 2.6 fold for the $20,50,100$ and $200 \mathrm{mg} / \mathrm{L} \mathrm{Mo}$ treatments, respectively, and these levels were all greater than the POD activity levels in tobacco plants supplemented with Mo in the absence of the $R$. solanacearum inoculation, as well as the activities of other defensed response enzymes (Figure S1A).

Figure $2 \mathrm{~B}$ shows that the activity of CAT significantly changed among the different treatments, and there were significant discrepancies between the Mo-treated and control group, even when foliar sprays of Mo were applied to healthy tobacco plants (Figure S1B). The CAT activity significantly improved by 2.31 fold when $200 \mathrm{mg} / \mathrm{L}$ Mo was applied to plants compared to that of the untreated control. In addition, the activities of CAT under the $100 \mathrm{mg} / \mathrm{L}$ and $50 \mathrm{mg} / \mathrm{L}$ Mo treatments were 1.51 and 1.34 fold greater, respectively, than those for the control. While the application of $20 \mathrm{mg} / \mathrm{L} \mathrm{Mo}$ increased the CAT activity by 1.07 fold compared to the control, a significant effect was not recorded. These results indicate that the application of Mo facilitated an improvement in the activity of CAT and that the high Mo treatment was the most effective. 
Table 1: Average molybdenum content of rhizospheric soil around infected tobacco and tobacco leaf tissue of Yunyan 87 and Nanjiang 3 after different treatment under field condition and greenhouse.

\begin{tabular}{|c|c|c|c|c|c|c|c|c|c|c|}
\hline \multirow{3}{*}{$\begin{array}{c}\text { Days After Treatment } \\
\text { (DAT) }\end{array}$} & \multirow{3}{*}{ Treatments $^{\times}(\mathrm{mg} / \mathrm{L})$} & \multicolumn{4}{|c|}{ Field Application } & \multirow{3}{*}{$\begin{array}{l}\text { Days after treatment } \\
\text { (DAI) }\end{array}$} & \multicolumn{4}{|c|}{ Greenhouse Application } \\
\hline & & \multicolumn{2}{|c|}{ Yunyan 87 (mg/kg) } & \multicolumn{2}{|c|}{ Nanjiang 3 (mg/kg) } & & \multicolumn{2}{|c|}{ Yunyan 87 (mg/kg) } & \multicolumn{2}{|c|}{ Nanjiang 3 (mg/kg } \\
\hline & & In Soil & In Leaf & In Soil & In Leaf & & In Soil & In Leaf & In Soil & In Leaf \\
\hline \multirow{9}{*}{75} & Water ${ }^{Y}$ & $0.105 a^{z}$ & $0.014 a$ & $0.114 a$ & $0.049 a$ & \multirow{9}{*}{14} & $0.006 a$ & $0.004 a$ & $0.002 a$ & $0.003 a$ \\
\hline & $+\mathrm{NH}_{4} \mathrm{NO}_{3}(3.7)$ & $0.108 a$ & $0.017 a$ & $0.111 \mathrm{a}$ & $0.056 a$ & & $0.006 a$ & $0.003 a$ & $0.004 a$ & $0.002 a$ \\
\hline & $+\mathrm{NH}_{4} \mathrm{NO}_{3}(7.5)$ & $0.111 \mathrm{a}$ & $0.018 a$ & $0.114 a$ & $0.042 a$ & & $0.005 a$ & $0.005 a$ & $0.004 a$ & $0.003 a$ \\
\hline & $+\mathrm{NH}_{4} \mathrm{NO}_{3}(15)$ & $0.109 a$ & $0.019 a$ & $0.113 a$ & $0.043 a$ & & $0.006 a$ & $0.004 a$ & $0.005 a$ & $0.002 \mathrm{a}$ \\
\hline & $+\mathrm{NH}_{4} \mathrm{NO}_{3}(30)$ & $0.116 b$ & $0.017 a$ & $0.118 \mathrm{a}$ & $0.042 a$ & & $0.004 a$ & $0.002 a$ & $0.003 a$ & $0.003 a$ \\
\hline & +Mo (20) & $0.096 a$ & $0.052 b$ & $0.098 \mathrm{a}$ & $0.046 a$ & & $0.005 a$ & $0.021 b$ & $0.004 \mathrm{a}$ & $0.031 \mathrm{a}$ \\
\hline & +Mo (50) & $0.115 b$ & $0.089 c$ & $0.131 b$ & $0.081 \mathrm{ab}$ & & $0.018 b$ & $0.043 c$ & $0.008 b$ & $0.057 a$ \\
\hline & +Mo (100) & $0.096 a$ & $0.132 d$ & $0.128 \mathrm{c}$ & $0.119 \mathrm{bc}$ & & $0.033 c$ & $0.065 d$ & $0.039 c$ & $0.095 b$ \\
\hline & + Mo (200) & $0.106 a$ & $0.137 d$ & $0.112 a$ & $0.132 d$ & & $0.022 d$ & $0.129 \mathrm{e}$ & $0.041 d$ & $0.125 c$ \\
\hline
\end{tabular}

${ }^{x}$ and ${ }^{+}$represent foliar nonsprayed and sprayed with $\left(\mathrm{NH}_{4}\right)_{6} \mathrm{MoO}_{24} \cdot 4 \mathrm{H}_{2} \mathrm{O}$, respectively. $+\mathrm{NH}_{4} \mathrm{NO}_{3}$ treatments represent the tobacco was sprayed with $\mathrm{NH}_{4} \mathrm{NO}_{3}$ which contains the same corresponding amount of nitrogen in contrast with +Mo treatments.

yeionized water was foliar applied in the greenhouse and field trails which were referred as untreated control.

zValues with the same uppercase letter in the same row did not differ significantly at $\mathrm{P}<0.05$ according to Fisher's protected least significant different test.

Table 2: Effect of different Mo treatments on morphological characteristics of Yunyan 87 tobacco plants and Nanjiang 3 at 14 DAl in greenhouse experiment.

\begin{tabular}{|c|c|c|c|c|c|c|c|}
\hline Year & $\begin{array}{l}\text { Treatment } \\
(\mathrm{mg} / \mathrm{L})\end{array}$ & $\begin{array}{l}\text { Plant height } \\
\text { (cm) }\end{array}$ & $\begin{array}{l}\text { Length of largest leaf } \\
(\mathrm{cm})\end{array}$ & $\begin{array}{c}\text { Width of largest leaf } \\
\text { (cm) }\end{array}$ & $\begin{array}{l}\text { Stem diameter } \\
(\mathrm{cm})\end{array}$ & $\begin{array}{c}\text { Number of productive } \\
\text { Leaves }\end{array}$ & $\begin{array}{c}\text { Area of largest leaf } \\
\left(\mathrm{cm}^{2}\right)\end{array}$ \\
\hline \multirow{5}{*}{$\begin{array}{c}\text { Yuanyan } \\
87\end{array}$} & 200 & $96.7 \pm 0.9^{\times} a$ & $70.6 \pm 1.2 a^{y}$ & $30.5 \pm 0.8 a$ & $10.0 \pm 0.4 a$ & $18.2 \pm 0.2 a$ & $1365.5 \pm 39.6 a$ \\
\hline & 100 & $93.6 \pm 2.8 \mathrm{ab}$ & $68.7 \pm 1.2 \mathrm{ab}$ & $29.5 \pm 0.4 a b$ & $9.7 \pm 0.0 \mathrm{a}$ & $17.7 \pm 0.6 a$ & $1284.0 \pm 39.7 b$ \\
\hline & 50 & $90.6 \pm 2.2 \mathrm{bc}$ & $67.9 \pm 1.3 b$ & $29.1 \pm 0.2 b$ & $9.0 \pm 0.1 b$ & $18.1 \pm 0.7 a$ & $1256.0 \pm 34.9 b$ \\
\hline & 20 & $89.1 \pm 1.1 \mathrm{~cd}$ & $67.8 \pm 0.4 b$ & $28.6 \pm 0.8 b c$ & $8.9 \pm 0.1 b$ & $17.2 \pm 0.8 a$ & $1231.2 \pm 26.2 \mathrm{bc}$ \\
\hline & $\mathrm{CK}$ & $86.3 \pm 2.0 \mathrm{~d}$ & $66.5 \pm 1.2 \mathrm{~b}$ & $27.8 \pm 0.5 c$ & $8.9 \pm 0.2 b$ & $17.5 \pm 0.8 \mathrm{a}$ & $1175.9 \pm 26.9 \mathrm{c}$ \\
\hline \multirow{5}{*}{ Nanjiang 3} & 200 & $113.9 \pm 1.8 a$ & $75.2 \pm 1.3 a$ & $33.9 \pm 0.7 a$ & $12.0 \pm 0.1 \mathrm{a}$ & $19.3 \pm 0.7 a$ & $1615.6 \pm 7.7 a$ \\
\hline & 100 & $106.7 \pm 4.5 b$ & $72.7 \pm 0.4 a b$ & $33.7 \pm 0.3 a$ & $11.8 \pm 0.1 \mathrm{ab}$ & $18.4 \pm 0.4 a$ & $1557.4 \pm 21.7 a$ \\
\hline & 50 & 109.1 $\pm 1.0 \mathrm{ab}$ & $72.3 \pm 1.9 b$ & $34.5 \pm 0.1 a$ & $11.5 \pm 0.3 b$ & $19.0 \pm 1.0 a$ & $1584.3 \pm 42.8 a$ \\
\hline & 20 & $106.4 \pm 3.0 b$ & $70.8 \pm 1.7 b$ & $32.7 \pm 1.6 a b$ & $11.6 \pm 0.1 \mathrm{ab}$ & $18.2 \pm 0.2 \mathrm{ab}$ & $1470.4 \pm 40.5 b$ \\
\hline & $\mathrm{CK}$ & $89.9 \pm 2.4 c$ & $67.2 \pm 1.3 c$ & $31.3 \pm 1.5 b$ & $10.7 \pm 0.3 c$ & $17.2 \pm 0.5 b$ & $1334.7 \pm 83.1 \mathrm{c}$ \\
\hline
\end{tabular}

${ }^{\times}$The values are means \pm standard deviations (SD).

Values with the same uppercase letter in the same row did not differ significantly at $\mathrm{P}<0.05$ according to Fisher's protected least significant different test.

The data indicate that there was a gradual increase in SOD activity with Mo concentrations increasing (Figure 2C). The activity of SOD under the $200 \mathrm{mg} / \mathrm{L}$ Mo treatment was 1.77 fold greater than that of the control, and the difference was significant. Furthermore, compared with the control, the addition of 100, 50 and $20 \mathrm{mg} / \mathrm{L} \mathrm{Mo}$ resulted in 1.58, 1.61 and 1.46-fold greater SOD activity, respectively. Similarly, 200mg/L Mo treatment increased the activity of PPO by 1.76 fold compared with the control, and the 100,50 and $20 \mathrm{mg} / \mathrm{L} \mathrm{Mo}$ treatments resulted in 1.56, 1.19 and 1.59 fold greater PPO activity, respectively. Figure 2E shows that the addition of Mo significantly enhanced the activity of PAL in tobacco leaves. The activity of PAL was $1.67,1.58,1.61$ and 1.46 times greater than that of the control after treatment with $200,100,50$ and $20 \mathrm{mg} / \mathrm{L} \mathrm{Mo}$, respectively. These results suggest that the $200 \mathrm{mg} / \mathrm{L}$ Mo treatment resulted in the highest PAL activity. These results suggest that Mo supplements are conducive to motivating the tobacco defense response and reducing the oxidative damage when $R$. solanacearum infects the plant, which can improve plant osmotic adjustment abilities under adverse situations, such as salt and drought stress [18,21].

\section{Content of malonaldehyde (MDA) in tobacco leaves}

The MDA levels of the Mo-treated groups were significantly lower than those of the control (Figure 2F). The 200mg/L Mo treatment resulted in the lowest MDA level, followed by the $100 \mathrm{mg} / \mathrm{L} \mathrm{Mo}$ treatment, and MDA was reduced by 0.54 and 0.51 times that of the control in the respective treatments. The MDA levels of the $50 \mathrm{mg} / \mathrm{L}$ and $20 \mathrm{mg} / \mathrm{L}$ Mo-treated groups were 0.41 and 0.39 fold lower than those of the control, respectively. Consequently, application of Mo to the plants was beneficial because it reduced the MDA content in the infected plants and decreased the degree of cytomembrane damage, especially at high concentrations. Even spraying an application Mo without the $R$. solanacearum inoculation reduced the MDA production, protecting plant cells from the oxidative stress (Figure S1).

\section{$R$. solanacearum populations in the roots and stems}

To determine whether foliage-spraying Mo can repress pathogens colonization in plants tissue, bacterial colonies in two tobacco varieties was tested (Figure 3 ). The results showed that lower populations of $R$. solanacearum were detected in the root and stem 
Table 3: Effect of different Mo treatments on morphological characteristics of Yunyan 87 tobacco plants and Nanjiang 3 at 75 DAT in field trails.

\begin{tabular}{|c|c|c|c|c|c|}
\hline Year & Treatment (mg/L) & Plant fresh weight (g) & Plant dry weight (g) & Root fresh weight (g) & Stem length $(\mathrm{cm})$ \\
\hline \multirow{5}{*}{ Yuanyan 87} & 200 & $9.72 \pm 0.5^{\times} \mathrm{a}$ & $2.25 \pm 0.1 a^{y}$ & $1.81 \pm 0.08 a$ & $10.7 \pm 0.6 a$ \\
\hline & 100 & $8.94 \pm 0.4 a$ & $1.97 \pm 0.2 a$ & $1.64 \pm 0.08 a$ & $9.8 \pm 0.5 a$ \\
\hline & 50 & $7.35 \pm 0.3 b$ & $1.75 \pm 0.1 b$ & $1.50 \pm 0.07 b$ & $9.5 \pm 0.4 a$ \\
\hline & 20 & $6.84 \pm 0.3 b c$ & $1.13 \pm 0.0 \mathrm{c}$ & $1.35 \pm 0.06 b$ & $8.9 \pm 0.4 b$ \\
\hline & $\mathrm{CK}$ & $6.65 \pm 0.3 c$ & $0.75 \pm 0.0 \mathrm{~d}$ & $1.27 \pm 0.06 b$ & $8.9 \pm 0.4 b$ \\
\hline \multirow{5}{*}{ Nanjiang 3} & 200 & $10.32 \pm 0.5 a$ & $2.31 \pm 0.1 a$ & $2.02 \pm 0.1 \mathrm{a}$ & $12.0 \pm 0.6 a$ \\
\hline & 100 & $9.28 \pm 0.4 b$ & $2.03 \pm 0.2 \mathrm{ab}$ & $1.88 \pm 0.3 a$ & $11.8 \pm 0.4 a b$ \\
\hline & 50 & $8.05 \pm 0.4 c$ & $1.75 \pm 0.3 b$ & $1.74 \pm 0.1 \mathrm{a}$ & $11.6 \pm 0.3 b$ \\
\hline & 20 & $7.35 \pm 0.2 d$ & $1.35 \pm 0.1 \mathrm{c}$ & $1.56 \pm 0.2 \mathrm{ab}$ & $11.5 \pm 0.1 \mathrm{ab}$ \\
\hline & $\mathrm{CK}$ & $7.21 \pm 0.3 d$ & $1.02 \pm 0.1 \mathrm{c}$ & $1.41 \pm 0.1 \mathrm{~b}$ & $10.7 \pm 0.5 \mathrm{c}$ \\
\hline
\end{tabular}

×The values are means \pm standard deviations (SD).

y Values with the same uppercase letter in the same row did not differ significantly at $\mathrm{P}<0.05$ according to Fisher's protected least significant different test.
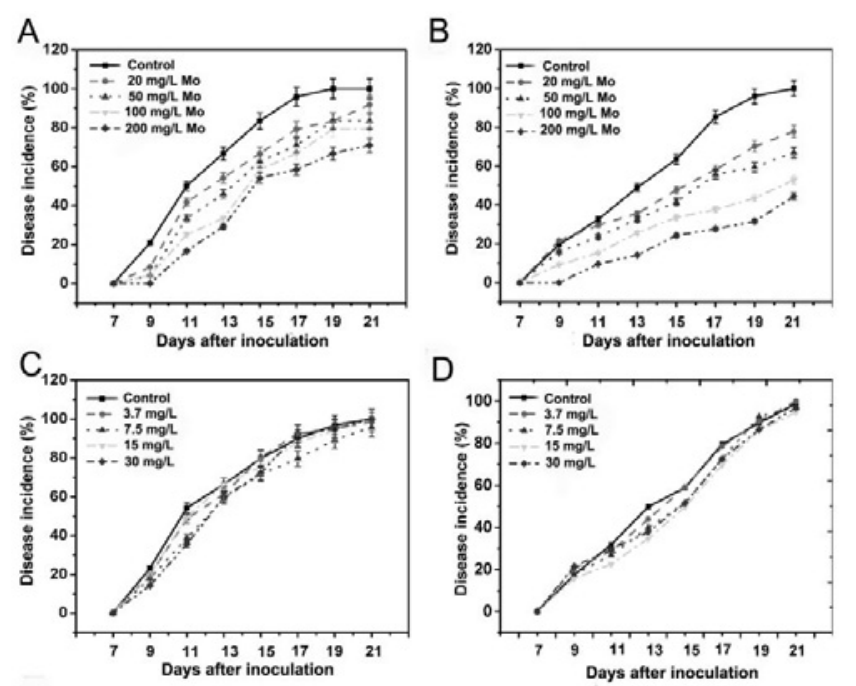

E

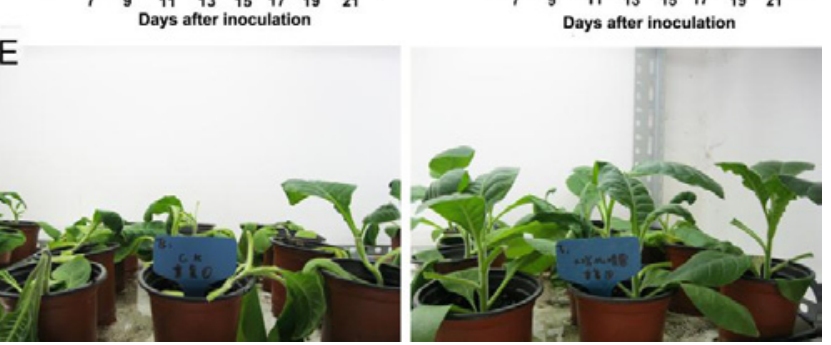

Figure 1: Bacterial wilt disease incidence of different tobacco cultivars in response to different treatments under greenhouse conditions. A, Mo; and $\mathrm{C}, \mathrm{NH}_{4} \mathrm{NO}_{3}$ treatments in Yunyan 87; $\mathrm{B}, \mathrm{Mo}$; and $\mathrm{D}, \mathrm{NH}_{4} \mathrm{NO}_{3}$ treatments in Nanjiang 3. (E) Morphological characteristics of Yunyan 87 tobacco plants before and after the R. solanacearum inoculation under Mo-deficient (control) and $200 \mathrm{mg} / \mathrm{L}$ Mo-supplied condition. The values represent the means \pm standard deviations of the three replicates. Error bars represent one standard deviation.

pieces from Yunyan 87 and Nanjiang 3 treated with Mo compared to the control. The bacterial content in tobacco treated with a low concentration $(20 \mathrm{mg} / \mathrm{L})$ of Mo at 1 and 7 DAI was not significantly different. However, at the later growth stages of 14 and 21 DAI, possibly after the plant had utilized the nutrient element, the bacteria colonializations were greatly decreased, especially in the $200 \mathrm{mg} / \mathrm{L}$ Mo-treated tobacco.
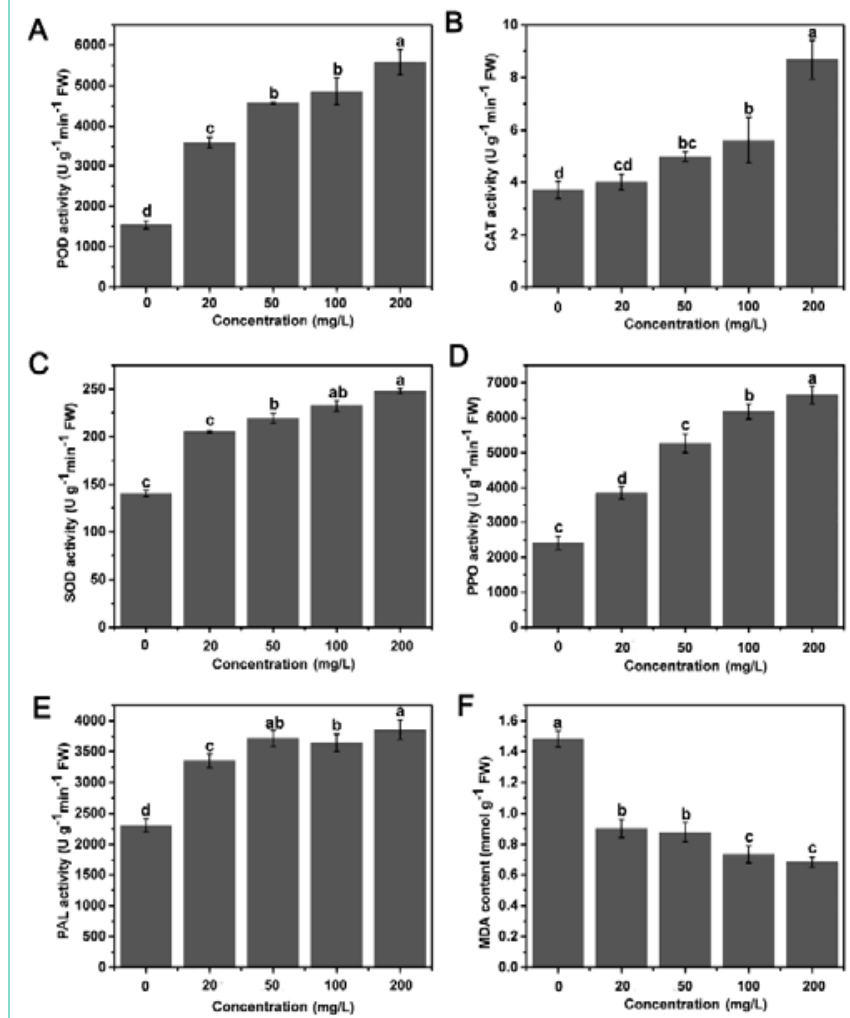

Figure 2: Effects of different Mo concentrations on the activity of resistancerelated enzymes and the MDA content in infected susceptible tobacco plants. A-F) Show the effects of different treatments on the POD, CAT, SOD, PPO and PAL activities and MDA content in infected tobacco plants at the initial stage of tobacco bacterial wilt, respectively. The values are means \pm standard deviations of the three replicates. Significant differences $(P<0.05)$ among treatments are indicated by different letters above the bars.

\section{Antibacterial activities of Mo against $R$. solanacearum}

The antibacterial activity of $\mathrm{Mo}$ and $\mathrm{NH}_{4} \mathrm{NO}_{3}$ against $R$. solanacearum in vitro were preliminarily investigated. Figure 4 displays the formation of bacterial colonies on the control and Motreated agar plates. The control plates filled only with NA medium showed many colonies after inoculation with $R$. solanacearum. However, Mo inhibited the bacterial growth, even inducing the 

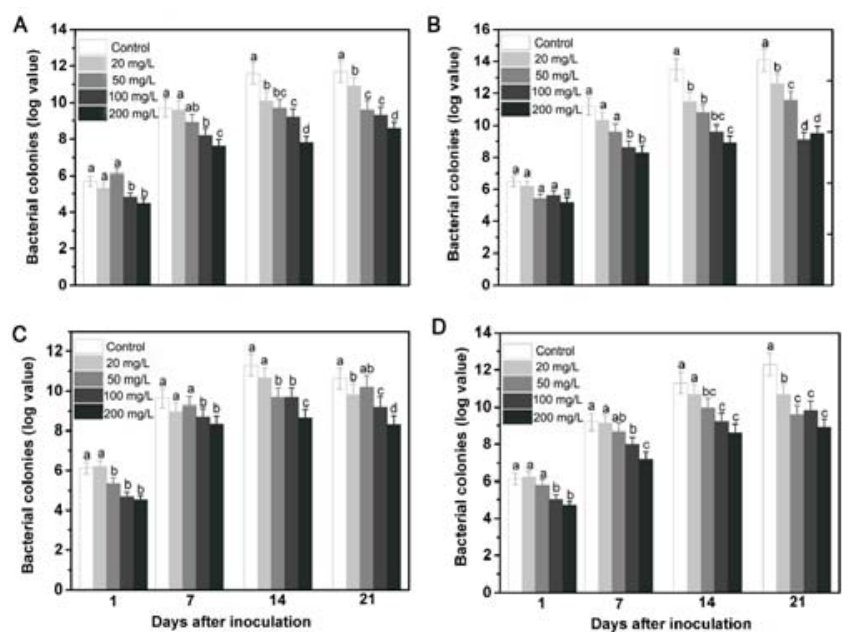

Figure 3: Bacterial colonies in two tobacco varieties after inoculation for 1 , 7,14 and 21 days after inoculation in the greenhouse experiment. Values represent the mean \pm standard errors of the three samples with three replicates for A: The roots of Yunyan 87; B) The roots of Nanjiang 3; C) The stems of Yunyan 87; D) The stems of Nanjiang 3. Error bars represent one standard deviation. Significant differences $(P<0.05)$ among treatments are indicated by different letters above the bars.

death of R. solanacearum. Bacterial colonies were reduced by $38.9 \%$, $81.8 \%$ and $100 \%$ compared to those of untreated samples. Notably, the bacteria were completely killed in the presence of $200 \mathrm{mg} / \mathrm{L} \mathrm{Mo}$ (Figure 4E). Additionally, the antibacterial activities of Mo improved when the Mo concentration increased. However, $\mathrm{NH}_{4} \mathrm{NO}_{3}$ did not seem to have antibacterial activity, as the number of colonies grown on the agar plates containing different concentrations of $\mathrm{NH}_{4} \mathrm{NO}_{3}$ were all the same as the control number (Figure S3).

\section{Effects of foliar application of Mo on bacterial wilt in field trials}

We investigated the occurrence of symptoms at the initial, infectious and later stages of the disease (45, 75 and 90 days after treatment, respectively) under different treatments in the field experiment. Based on the results, the control exhibited the most severe symptoms, whereas the incidence and severity of tobacco bacterial wilt gradually significantly decreased by increasing foliar supplements of Mo for both Yunyan 87 and Nanjiang 3 (Figure 5). According to our survey, the disease onset was delayed by an average of 7 days by the foliar Mo treatments. The disease progressed slowly under the $200 \mathrm{mg} / \mathrm{L}$ Mo treatments, such that the disease incidence and severity were the lowest. Compared with the control, at the later stage of the disease, the disease incidence of Yunyan 87 decreased by $30.3 \%$ and $29.5 \%$ under the 200 and $100 \mathrm{mg} / \mathrm{L}$ Mo treatments. The disease incidence of Nanjiang 3 was reduced by $33.9 \%$ and $25.4 \%$ under the 200 and $100 \mathrm{mg} / \mathrm{L}$ Mo treatments, respectively (Figure 5B and $5 \mathrm{C}$ ). Similar to the results in the greenhouse experiment, $\mathrm{N}$ played a small role in the resistance of tobacco against $R$. solanacearum in the repeated field experiments. There were no significant differences between the control and $\mathrm{N}$ treatments. The corresponding control efficacy in the later stage reached $46.9 \%$ for Yunyan 87 and 51.2\% for Nanjiang 3. During the two years of field trials, the control efficacies of the 100,50 and $20 \mathrm{mg} / \mathrm{L}$ Mo treatments against tobacco bacterial wilt ranged from $41.7-53.9 \%, 39.1-51.8 \%$ and $32.8-47.0 \%$, respectively (Figure S4B), and from 43.9-47.8 \%, 42.4-46.8 \% and 38.3-41.8 $\%$, respectively (Figure S4C). The remarkable control effect under field conditions is intuitively shown in Figure 5A. Tobacco plants amended with Mo grew increasingly vigorously with increasing Mo concentration, while the non-Mo-supplemented tobacco exhibited severe bacterial wilt.

\section{Foliar Mo application promotes tobacco plants growth}

Under greenhouse conditions, the growth of the non-inoculated Mo-treated tobacco plants was better than that of the plants not treated with Mo. Fourteen DAI, the plant fresh weight, plant dry weight, root fresh weight and stem length were significantly increased by $31.5 \%$, $30.2 \%, 49.7 \%$ and $25.4 \%$ (Yunyan 87 ) and $30.1 \%, 56.2 \%, 30.2 \%$ and $10.8 \%$ (Nanjiang 3) for Mo concentrations of 200, 100, 50 and 20 $\mathrm{mg} / \mathrm{L}$, respectively (Table 2). Similarly, in the field assay, the results for both growth stages ( 45 and 75 DAT) were almost identical (Table S4 and Table 3). It can be seen that Mo application had conducive
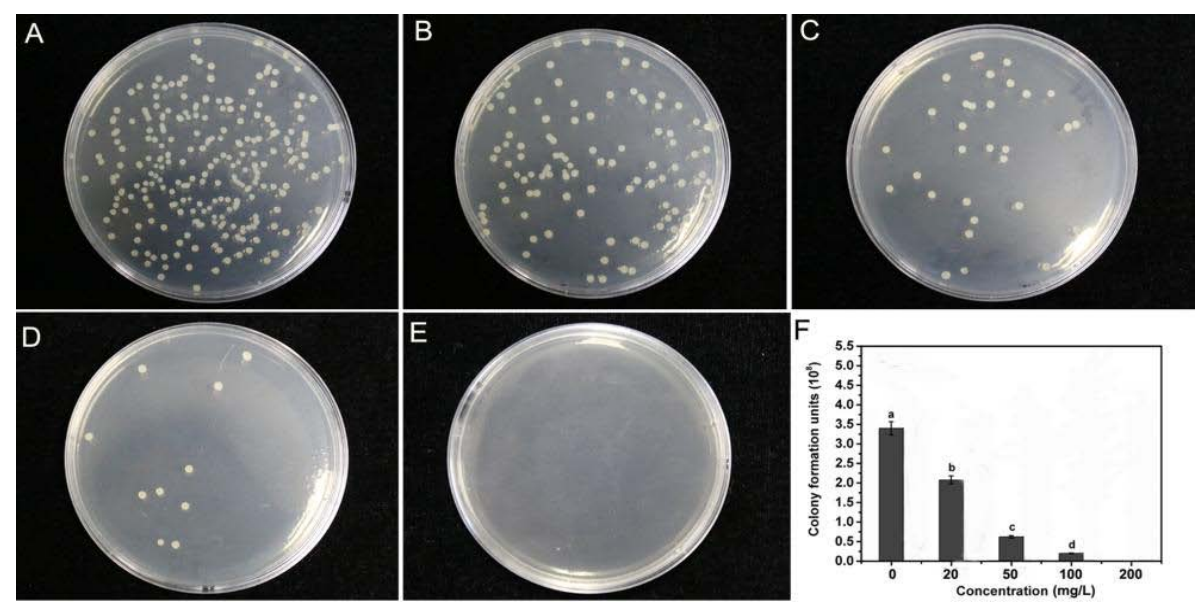

Figure 4: Effects of different concentrations of Mo on the R. solanacearum populations on agar plates. A: Omg/L; B: 20mg/L; C, 50mg/L; D, 100mg/L; E, 200mg/L. F: Viability of R. Solanacearum cells after treatments with different concentrations of Mo. $R$. solanacearum cells were spread on NA agar medium supplied with different concentrations of Mo and cultured in an incubator for three days at $30^{\circ} \mathrm{C}$. Error bars represent one standard deviation. The same uppercase letter above the column indicates that it did not differ significantly at $P<0.05$ as denoted by Fisher's protected least significant difference test. 

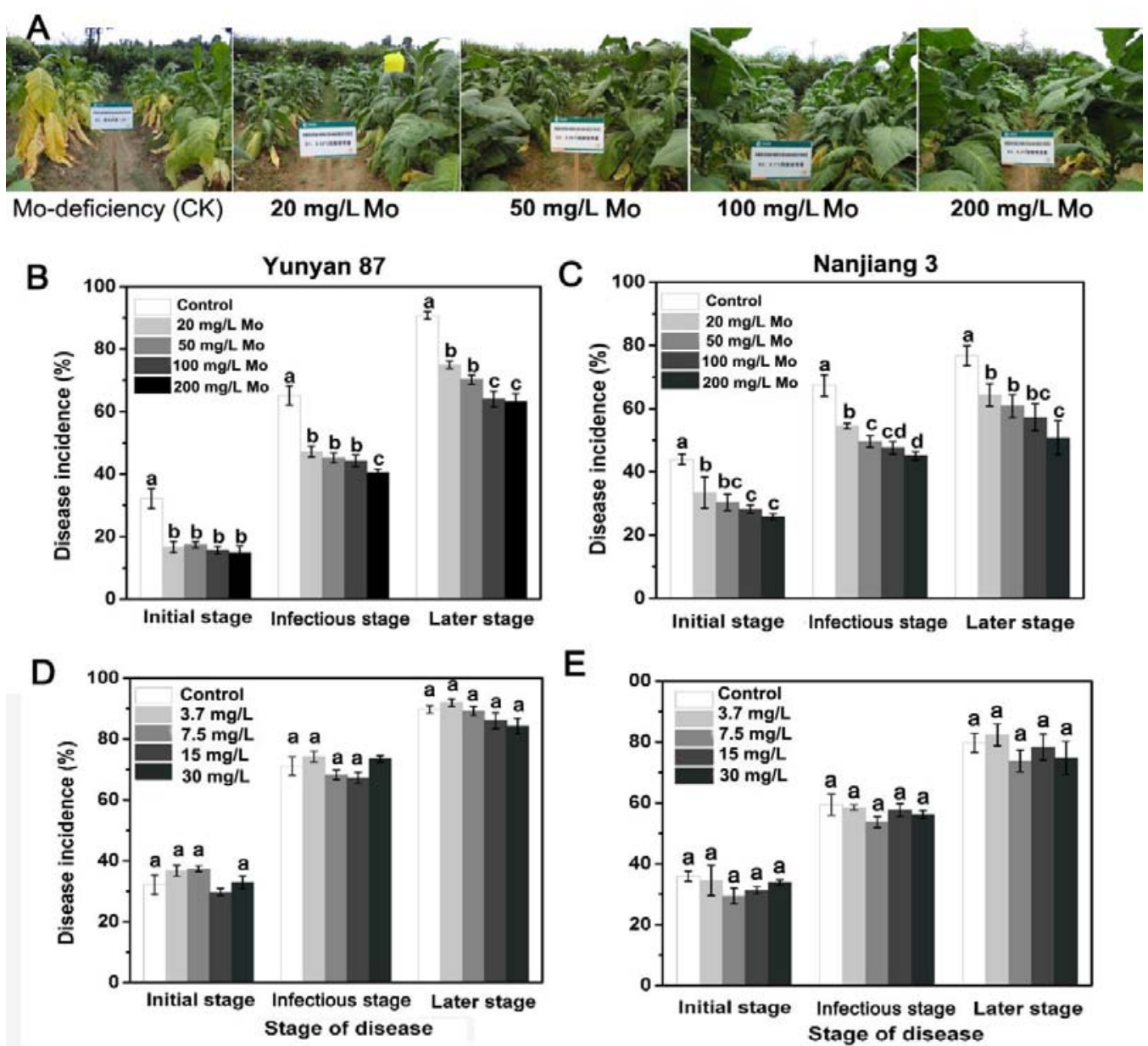

Figure 5: Comparison of the disease occurrence of tobacco bacterial wilt under different treatments in the field trails. A: Morphology of tobacco plants cultivated in Mo-deficient and Mo-supplied soil in the field; B and C: Show the control efficacies of the Mo treatment against bacterial wilt in Yunyan 87 and Nanjiang 3 , respectively. $\mathrm{D}$ and $\mathrm{E}$ : Show the control efficacies of the $\mathrm{NH}_{4} \mathrm{NO}_{3}$ treatment against tobacco bacterial wilt, respectively. The values are means \pm standard deviations of three replicates. Significant differences $(P<0.05)$ among treatments are indicated by different letters above the bars.

effects on the tobacco growth. After foliar spraying of $200 \mathrm{mg} / \mathrm{L} \mathrm{Mo}$ on tobacco in the field, there were significant increases in the plant height, the length and width of the largest leaf, the stem diameter, and the area of the largest leaf in the Mo-treated plants compared to the control plants. These results suggest that supplemental application of Mo had a dose-dependently positive effect on the growth and development of tobacco in the field and, to a certain degree.

\section{Discussion}

The effects of foliar-sprayed Mo on tobacco growth and bacterial wilt disease under greenhouse and field conditions were evaluated in this study. The results indicate that foliar-applied Mo solution significantly reduced bacterial wilt caused by $R$. solanacearum by increasing the ability of tobacco to resist infection. The application of Mo postponed and reduced the occurrence of and damage from tobacco bacterial wilt for both a susceptible variety (Yunyan 87) and moderate resistant (Nanjiang 3), The data suggest that with higher concentrations of Mo, the more slowly tobacco bacterial wilt develops. Moreover, supplement of Mo improved tobacco plant growth whether in laboratory or in the field.
In addition, $\mathrm{NH}_{4} \mathrm{NO}_{3}$ treatments were parallelly intended to discriminate among $\mathrm{N}$ effects on disease wilt control across all experiments. $\mathrm{N}$ application did not effectively control the bacterial wilt, because plant resistance regulatory network can be severely constrained under limiting supply, but high $\mathrm{N}$ condition was beneficial for plant resistance elicitation, protein contents and peroxidase and chitinase activity were significantly higher than controls in Arabidopsis thaliana plants [37]. Therefore, we deduced that Mo was a likely contributing factor in controlling bacterial wilt disease (Figure S1 and S2). These results indicate that Mo nutrition played a significant role in the greenhouse and field management of bacterial wilt.

In a preliminary study, significant differences in Mo levels were detected between the rhizosphere soil of healthy tobacco plants and that of plants severely infected with $R$. solanacearum [38]. Similarly, Gupta and Lipsett reported active Mo content was lower in the rhizosphere soil of diseased plants than in that of healthy tobacco plants.17 The findings imply that the level of Mo in soil is associated to the development of bacterial wilt disease, even it can be speculated that lower levels of available Mo in tobacco-growing 
soil are one of the key factors for disease occurrence, just like $\mathrm{Mg}$, Si and $\mathrm{B}[7,8,10]$. Mo deficiency is common in most cultivated field in Chongqing areas. The soil samples collected from Qianjiang tobaccoplanting districts was acidified (Table 1). The active Mo content of rhizosphere soil in typical tobacco growing areas in Chongqing was below the recommended, which is about from 0.5 to $5 \mathrm{mg} / \mathrm{kg}$ soil $[17,21]$. Johnson et al. suggested $0.5 \mathrm{mg} / \mathrm{kg}$ Mo in the whole dry plant material was indicative of adequate molybdenum in soils [39]. Therefore, frequent precipitation and low soil $\mathrm{pH}(\mathrm{pH}<5.5)$ are likely responsible for the Mo deficiency [40]. As we known, plant species and soil characteristics, including nutrient and soil $\mathrm{pH}$, differently affect uptake, accumulation and availability of Mo in plant [21]. In this work, $200 \mathrm{mg} / \mathrm{L}$ ammonium molydate supplied about $0.109 \mathrm{~g} / \mathrm{mL}$ (calculated equal molar) was applied, but the Mo content in leaves was determined to $0.137 \mathrm{mg} / \mathrm{kg}$ compared to the control $(0.014 \mathrm{mg} /$ $\mathrm{kg}$ ) (Table 1). The reason may be associated to the extreme low Mo content in growing soil and the inefficient absorption (because of acidifying soil), because $\mathrm{Mo}$ is accessible to plants in its soluble anion form $\mathrm{MoO}^{-4}$ in alkaline conditions [21].

In our experiments, Mo was accumulated in tobacco leaves both in the greenhouse and field condition, but Mo contents in soil were gradually decreased with the tobacco growth, which showed that Mo was absorbed and mainly transferred in tobacco. The application of different concentration of $\mathrm{N}$ did not affect Mo uptake efficiency from either the soil and in leaves. At the same time, foliar-sprayed Mo stimulated tobacco leaves to take up more Mo than Mo-deficient tobacco leaves did at all stages. Nutrient elements applied by foliar spraying are commonly absorbed by the leaf through the cuticle and epidermal cells and are translocated to other plant parts, including the roots, via phloem [41]. Mo is found primarily in the phloem and the vascular bundle parenchyma of plants and is transported in the phloem [42]. Once Mo is taken up by tobacco, the activities of nitrate reductase and the Mo-Fe protein of dinitrogenase in plants become simulated, and plant nitrogen metabolism is promoted [43]. Consequently, the foliar supplements of Mo enhanced tobacco growth, as indicated in Table 2 and Table 3. Our findings indicated that foliar supplement of Mo significantly promoted the growth of two tobacco cultivars under greenhouse condition without $R$. solanacearum stress under field condition, which is similar to the positive effects on tomato, cauliflower, soybean, oilseed and wheat, even under abiotic stress [21,44,45]. Other micronutrients including $\mathrm{N}, \mathrm{P}, \mathrm{B}, \mathrm{Mn}$ and $\mathrm{Zn}$ were all reported similar growth-promoting effects on crop [41].

Furthermore, nutritional approaches can overcome the drawbacks of chemical control. Adjusting mineral nutrition is worth exploring for plant disease because of the positive effects on the interaction between host plants and pathogens [10,41]. Mo may also control disease severity, but the mechanism of action remains to be studied. Abundant mineral elements not only are beneficial for imparting plant defense responses but also are important for many metabolites, such as sugars and amino acids [46]. We found that the addition of Mo appears to increase the defense-related enzymes activity in tobacco plants (Figure 3). The capacity of Mo for increased tobacco resistance to bacterial wilt is attributed to improve activity of defenserelated enzymes and decrease the level of MDA. MDA is considered an indicator for ROS level, which can cause membrane damage and cell death in host plant when pathogens invaded, which agrees with the results of previous studies [28]. We also observed that when foliar spraying Mo alone without $R$. solanacearum infection on tobacco, the activities of defense-related enzymes were not altered or moderately improved (Figure S1). These results suggest that Mo supplements are conducive to motivating the tobacco defense response and reduce the oxidative damage when $R$. solanacearum infect the plant, which can improve plant osmotic adjustment abilities under adverse situations such as salt and drought stress $[21,26,47]$. Huber et al. indicated that minerals not only play an important role in promoting plant cell wall thickening, forming a mechanical barrier to resist pathogens, but also optimize the natural plant defense mechanism, in which they facilitate the secretion or synthesis of antioxidants, phytoalexins, flavonoids and other compounds in plants $[48,49]$. Wang et al. demonstrated that an exogenous $2 \mathrm{mM}$ Si treatment reduced the disease index of bacterial wilt by $19.18 \%$ to $52.7 \%$ [50]. It has previously been reported that maize exhibits significantly greater resistance against the fungal pathogens Fusarium oxysporum and Aspergillus niger when treated with nanosilica (20-40 nm) as well as greater expression of phenolic compounds (2056 and $743 \mathrm{mg} / \mathrm{mL}$, respectively) [51].

Interestingly, Mo was proven to exhibit strong antibacterial activities against $R$. solanacearum in vitro as assessed by the plating count method, completely suppressing the propagation of $R$. solanacearum under the high dosage of $200 \mathrm{mg} / \mathrm{L}$ (Figure 3). It demonstrated that to greatly extent application of Mo exactly blocked pathogen invasion. However, based on existing investigations, there is little research on the detailed antibacterial mechanisms of Mo. It may disrupt processes needed for cell growth in a manner that is influenced by the physical and chemical properties, causing oxidative stress, protein dysfunction or membrane damage [52]. We cannot clarify the detailed antibacterial activity at present. But what is clear is that, unlike other metals, presenting as cationic form, Mo is usually either coordinated by organic compounds in their surroundings or present as water-soluble oxyanion species, such as $\mathrm{MoO}^{4-}$ and $\mathrm{NH} 4 \mathrm{Mo}^{2+}$ [53]. Moreover, $\mathrm{NH}_{4} \mathrm{Mo}^{2+}$ was reported as a stimulus to product antimicrobial polyketides $\mathrm{Phl}$, mono-acetylphloroglucinol and pyrrolnitrin by biocontrol agent, a disease-suppressive strain of Pseudomonas fluorescens [54]. So, it is possible that Mo can irritate the antibacterial substance secretions by other beneficial microorganism in agricultural soil. The above results indicate that $\mathrm{Mo}$ was transported from leaves to roots. Therefore, we speculate that Mo interacts with the bacteria colonized in the stems and roots and other plant parts during the transportation process.

Most importantly, as we known, Yunyan 87 and Nanyang 3 are widely planted in the most regions in China. Our results provide valuable agricultural management strategy, although there are complex and diverse factors in growth environment. These results demonstrated that, with the lack of Mo in Chongqing cultivated fields even in China, foliar supplement of Mo is an effective measurement for controlling tobacco disease wilt. Exploring the relationships among Mo nutrition, host plant resistance and $R$. solanacearum will be of great importance for controlling bacterial wilt by improving the natural defensive abilities of plants. In addition, there are many relevant avenues for further research, such as applying Mo supplements to impact rhizosphere microbial communities, which plays important roles in both the suppression of bacterial wilt [55] 
and the molecular mechanisms of Mo nutrition with respect to host plant resistance and $R$. solanacearum infection.

\section{Conclusion}

Application of micronutrients is an environmentally friendly strategy for the management of crop diseases and constitutes an alternative method of agricultural sustainable development. However, studies on the relationship between Mo and tobacco growth and bacterial wilt are scarce. This is the first report on the effect of foliarsupplemented Mo nutrition on the management of tobacco bacterial wilt both in the greenhouse and in the field. Foliar-sprayed applications of Mo could effectively delay or prevent the occurrence or outbreak of tobacco bacterial wilt. Treatment with $200 \mathrm{mg} / \mathrm{L}$ Mo can significantly increases the activity of defensive enzymes in tobacco, improves tobacco disease resistance, inhibits bacteria reproduction and reduces both the incidence and index of tobacco bacterial wilt. Furthermore, Mo amendment is of significant benefit for optimizing plant height, the length and width of leaves, stem diameter and leaf area. Liebig's Law of Minimum states that plant growth is not determined by the total amount of resources available but by the scarcest resource. Given the results above, we suggest that future cultivation of tobacco should consider the application of Mo fertilizer. Supplemental Mo can be an effective approach and sustainably strategy to suppress wilt disease development, especially in tobacco-growing areas where soil Mo levels are deficient.

\section{Acknowledgment}

The authors gratefully acknowledge the financial support from National Natural Science Foundation of China (32001934), Fundamental Research Funds for the Central Universities (XDJK2019C076) and the Key Project of the State Tobacco Monopoly Administration (NY20130501070005).

\section{References}

1. Peeters N, Guidot A, Vailleau F, Valls M. Ralstonia solanacearum, a widespread bacterial plant pathogen in the post-genomic era. Mol. Plant Pathol. 2013; 14: 651-662.

2. Jiang GF, Wei Z, Xu J, Wei Z, Xu J, Chen H, et al. Bacterial wilt in China: history, current status, and future perspectives. Front. Plant Sci. 2017; 8: 1549.

3. Kim BS, French E, Caldwell D, Harrington EJ, Iyer-Pascuzzi AS. Bacterial wilt disease: Host resistance and pathogen virulence mechanisms. Physiolo. Mol. Plant P. 2016; 95: 37-43.

4. Nion YA, Toyota K. Recent trends in control methods for bacterial wilt diseases caused by Ralstonia solanacearum. Microbes Environ. 2015; 30: 1-11.

5. Bonanomi G, Lorito M, Vinale F, Woo SL. Organic amendments, beneficial microbes, and soil microbiota: toward a unified framework for disease suppression. Ann. Rev. Phytopathol. 2018; 56: 1-20.

6. Carazo-Rojas E, Pérez-Rojas G, Pérez-Villanueva M, Chinchilla-Soto C, Chin-Pampillo JS, Aguilar-Mora P, et al. Pesticide monitoring and ecotoxicological risk assessment in surface water bodies and sediments of a tropical agro-ecosystem. Environ. Pollut. 2018; 241: 800-809.

7. Khatri K, Vallad G, Peres N, Desaegaer J, Regmi H, Boyd N. Efficacy of metam potassium on Fusarium oxysporum, Macrophomina phaseolina, Meloidogyne javanica, and seven weed species in microcosm experiments. Pest Manag Sci. 2021; 77: 869-876.

8. Jiang JF, Wan X, Li JG, Dong YH. Effect of boron nutrition on resistance response of tomato against bacterial wilt caused by Ralstonia Solanacearum.
J. Plant Patholo. 2016; 98: 117-122.

9. Ferreira HA, Nascimento CWAD, Datnoff LE, Nunes GHDS, Preston W, Souza EBD, et al. Effects of silicon on resistance to bacterial fruit blotch and growth of melon. Crop Prot. 2015; 78: 277-283.

10. Ota M, Imada K, Sasaki K, Kajihara H, Sakai S, It SI. MgO-induced defence against bacterial wilt disease in Arabidopsis thaliana. Plant Pathol. 2019; 68: 323-333.

11. Atim M, Beed F, Tusiime G, Tripathi L, Asten PV. High potassium, calcium, and nitrogen application reduce susceptibility to banana Xanthomonas wilt caused by Xanthomonas campestris pv musacearum. Plant Dis. 2013; 97 : 123-130.

12. Radhi MZA, Adam MB, Saud HM, Hamid MN, Tony PSH, Tan GH. Efficacy of smart fertilizer for combating bacterial wilt disease in Solanum Lycopersicum. J. Agric. Food Sci. 2016; 4: 137-143.

13. Dutta BK, Bremner E. Trace elements as plant chemotherapeutants to control Verticillium wilt. Zeitschrift fuer Pflanzenkrankheiten und Pflanzenschutz. 1981; 88: 405-412.

14. Jesus Júnior WC, Vale FXR, Coelho RR, Hau B, Zambolim L, Berger RD. Management of angular leaf spot in common bean (Phaseolus vulgaris $L$ ) with molybdenum and fungicide. Agron. J. 2004; 96: 665-670.

15. Polanco LR, Rodrigues FA, Moreira EN, Duarte HSS, Cacique IS, Valente LA, et al. Management of anthracnose in common bean by foliar sprays of potassium silicate, sodium molybdate, and fungicide. Plant Dis. 2014; 98 : 84-89.

16. Nie Z, Hu C, Tan Q, Sun X. Gene expression related to molybdenum enzyme biosynthesis in response to molybdenum deficiency in winter wheat. J. Soil Sci. Plant Nut. 2016; 16: 979-990.

17. Gupta UC, Lipsett J. Molybdenum in soils, plants, and animals. Adv. Agron. 1981; 34: 73-115

18. Silva MS, Oliveira GRF, Merloti LF, Bossolani JW, Camargos LS, Sá ME, et al. New insights on molybdenum fertilization in common bean under notillage system: rates and application time to obtain high vigor seeds. J Plant Nutr. 2020.

19. Sun XC, Tan QL, Nie ZJ, Hu CX, An YQ. Differential expression of proteins in response to molybdenum deficiency in winter wheat leaves under lowtemperature stress. Plant Mol. Biol. Rep. 2014; 32: 1057-1069.

20. Steinberg RA. Symptoms of molybdenum deficiency in tobacco. Plant Physiol. 1953; 2: 319-322.

21. Kaiser BN, Gridley KL, Brady JN, Phillips T, Tyerman SD. The role of molybdenum in agricultural plant production. Ann. Bot-London. 2005; 96: 745-754.

22. Halsall DM. Effects of certain cations on the formation and infectivity of Phytophthora zoospores: II Effects of copper, boron, cobalt, manganese, molybdenum and zinc ions. Can. J. Microbiol. 1977; 23: 1002-1010.

23. Al-Issawi M, Rihan HZ, Woldie WA, Burchett S, Fuller MP. Exogenous application of molybdenum affects the expression of CBF14 and the development of frost tolerance in wheat. Plant Physiol. Bioche. 2013; 63: 7781.

24. Al-Issawi M, Rihan HZ, Al-Shmgani H, Fuller MP. Molybdenum application enhances antioxidant enzyme activity and COR15a protein expression under cold stress in wheat. J. Plant Interact. 2016; 11: 5-10.

25. Babenko ON, Brychkova G, Sagi M, Alikulov ZA. Molybdenum application enhances adaptation of crested wheatgrass to salinity stress. Acta Physiol. Plant. 2005; 37: 1-13

26. Zhang M, Hu CX, Zhao XH, Tan QL, Sun XC, Cao AY, et al. Molybdenum improves antioxidant and osmotic-adjustment ability against salt stress in Chinese cabbage (Brassica campestris L. ssp. Pekinensis). Plant Soil. 2012; 355: 375-383.

27. Suzuki N, Katano K. Coordination between ROS regulatory systems and other pathways under heat stress and pathogen attack. Front. Plant Sci. 2018; 9: 490. 
28. Gong D, Bi Y, Li Y, Zong Y, Han Y, Prusky D. Both Penicillium expansum and Trichothecim roseum infections promote the ripening of apples and release specific volatile compounds. Front. Plant Sci. 2019; 10: 338

29. Liu Y, Wu DS, Liu Q, Zhang ST, Tang YM, Jiang GF, et al. The sequevar distribution of Ralstonia solanacearum in tobacco-growing zones of China is structured by elevation. J. Plant Pathol. 2017; 3: 541-551.

30. Zhu Z, Wei G, Li J, Qian Q, Yu J. Silicon alleviates salt stress and increases antioxidant enzymes activity in leaves of salt-stressed cucumber (Cucumis sativus L). Plant Sci. 2004; 167: 527-533.

31. Liang YC, Sun WC, Si J, Romheld V. Effects of foliar- and root-applied silicon on the enhancement of induced resistance to powdery mildew in Cucumis sativus. Plant Pathol. 2005; 54: 678-685.

32. Mulvaney RL, Khan SA. Diffusion methods to determine different forms of nitrogen in soil hydrolysates. Soil Sci. Soc. Am. J. 2001; 65: 1284-1292.

33. Schulte EE. Recommended soil-testing procedures for the North Eastern USA Northeastern Regional Publication. 1995

34. Ghaedi M, Niknam K, Shokrollahi A, Niknam E, Rajabi HR, Soylak M. Flame atomic absorption spectrometric determination of trace amounts of heavy metal ions after solid phase extraction using modified sodium dodecyl sulfate coated on alumina. J. Hazard. Mater. 2008; 155: 121-127.

35. Godiard L, Sauviac L, Torii KU, Grenon O, Mangin B, Grimsley NH, et al. ERECTA, an LRR receptor-like kinase protein controlling developmen pleiotropically affects resistance to bacterial wilt. Plant J. 2003; 36: 353-365.

36. Bibak A, Moberg JP, Borggaard OK. Content and distribution of cobalt, copper, manganese and molybdenum in danish spodosols and ultisols. Acta Agr Scand B-S P. 1994; 44: 208-213.

37. Dietrich R, Ploss K, Heil M. Constitutive and induced resistance to pathogens in Arabidopsis thaliana depends on nitrogen supply. Plant Cell Environ. 2004 27: 896-906.

38. Zheng SY, Chen DJ, Ding W, Du GP, Liu YQ, Cheng XL, et al. Nutritional status of rhizosphere soil around bacterial wilt diseased tobacco plant. Acta Tabacaria Sinica. 2014: 2057-2064.

39. Johnson CM. Pearson GA and Stout PR. Molybdenum nutrition of crop plants. Plant Soil. 1952; 4: 178-196.

40. He ZLL, Yang XE, Stoffella PJ. Trace elements in agroecosystems and impacts on the environment. J. Trace Elem. Med. Bio. 2005; 19: 125-140.

41. Fernandez $\mathrm{V}$, Brown $\mathrm{PH}$. From plant surface to plant metabolism: the uncertain fate of foliar-applied nutrients. Front. Plant Sci. 2013; 4: 289.

42. Tejada-Jiménez M, Chamizo-Ampudia A, Galván A, Fernández E, Llamas Á Molybdenum metabolism in plants. Metallomics.2013; 5: 1191-1203.
43. Evans $\mathrm{H}$, Hall $\mathrm{N}$. Association of molybdenum with nitrate reductase from soybean leaves. Science. 1955; 122: 922-923.

44. Wu SW, Sun XC, Tan Q, Hu C. Molybdenum improves water uptake via extensive root morphology, aquaporin expressions and increased ionic concentrations in wheat under drought stress. Environ Exp Bot. 2019; 157: 241-249.

45. Qin S, Hu C, Tan Q, Sun X. Effect of molybdenum levels on photosynthetic characteristics, yield and seed quality of two oilseed rape (Brassica napus $L$ ) cultivars. Soil Sci. Plant Nutr. 2017; 63: 137-144.

46. Luciano ÁJ, Irineo TP, Virginia OVR, Feregrino-Pérez AA, Hernández AC Gerardo GGR. Integrating plant nutrients and elicitors for production of secondary metabolites, sustainable crop production and human health: a review. Int. J. Agric. Boil. 2017; 19: 391-402.

47. Wu SW, Hu C, Tan Q, Nie Z, Sun X. Effects of molybdenum on water utilization, antioxidative defense system and osmotic-adjustment ability in winter wheat (Triticum aestivum) under drought stress. Plant Physiol. Bioch. 2014; 83: 365-374

48. Huber DM. The role of mineral nutrition in defense. Plant Dis. 1980; 5: 381 405.

49. Schjoerring JK, Cakmak I, White PJ. Plant nutrition and soil fertility: synergies for acquiring global green growth and sustainable development. Plant Soil. 2018; 434: 1-6.

50. Wang L, Cai KZ, Chen YT, Wang GP. Silicon-mediated tomato resistance against Ralstonia solanacearum is associated with modification of soil microbial community structure and activity. Biol. Trace Elem. Res. 2013; 152: 275-283.

51. Suriyaprabha R, Karunakaran G, Kavitha K, Yuvakkumar R, Rajendran V Kannan N. Application of silica nanoparticles in maize to enhance fungal resistance. LET Nanobiotechnol. 2014; 8: 133-137.

52. Lemire JA, Harrison JJ, Turner RJ. Antimicrobial activity of metals: mechanisms, molecular targets and applications. Nat. Rev. Microbiol. 2013; 6: 371-384.

53. Gadd GM. Metals, minerals and microbes: geomicrobiology and bioremediation. Microbiology. 2010; 156: 609-643.

54. Duffy BK, Défago G. Environmental factors modulating antibiotic and siderophore biosynthesis by Pseudomonas fluorescens biocontrol strains. Appl. Environ. Microb. 1999; 6: 2429-2438.

55. Liu XJ, Zhang ST, Jiang QP, Bai YN, Shen GH, Li SL, et al. Using community analysis to explore bacterial indicators for disease suppression of tobacco bacterial wilt. Sci. Rep-UK. 2016; 6: 36773. 